\title{
CANGKANG BUAH KARET DENGAN PEREKAT LIMBAH PLASTIK POLIPROPILENA SEBAGAI ALTERNATIF PAPAN PARTIKEL
}

\author{
Charles Banon ${ }^{1 *}$, Teja Dwi Sutanto ${ }^{1}$, Irfan Gustian ${ }^{1}$, Ilman Koharudin $^{1}$, Widia Rahmi ${ }^{2}$ \\ ${ }^{1}$ Jurusan Kimia Fakultas Matematika dan Ilmu Pengetahuan Alam \\ Universitas Bengkulu \\ ${ }^{2}$ Madrasah Aliyah Negeri 1 Kota Bengkulu \\ "email: banonc89@yahoo.com
}

\begin{abstract}
Abstrak
Telah dilakukan pembuatan dan karakterisasi mekanik papan partikel berbasis cangkang buah karet dengan perekat limbah plastik polipropilen. Papan partikel dibuat dengan variasi berat serbuk cangkang buah karet masing-masing 50 gram, 100 gram dan 150 gram, dicetak dengan ukuran $28 \mathrm{~cm} \times 12 \mathrm{~cm} \times 4 \mathrm{~cm}$. Campuran serbuk cangkang dan perekat selanjutnya dikempa menggunakan alat press sederhana selama 1 jam dalam keadaan panas, kemudian didiamkan selama 7 hari pada suhu kamar. Karakterisasi papan partikel meliputi pengujian sifat fisika dan sifat mekanik. Papan partikel yang terbuat dari limbah plastik polipropilena dan cangkang buah karet memiliki kerapatan 0,81-0,88 $\mathrm{g} / \mathrm{cm}^{3}$, kadar air $0,34-0,93 \%$, daya serap air 5,67 - 10,69\% dan tebal pengembangan 0,26 - 1,62\%. Hasil uji sifat mekanik papan partikel dari serbuk cangkang buah karet dan plastik polipropilena menunjukkan nilai keteguhan patah $53-56,54 \mathrm{kgf} / \mathrm{cm}^{2}$, nilai keteguhan elastis $253,85-400,87 \mathrm{kgf} / \mathrm{cm}^{2}$ dan kuat cabut sekrup sebesar $1,96 \mathrm{kgf} / \mathrm{cm}^{2}$.
\end{abstract}

Kata kunci: Cangkang buah karet, polipropilena, papan partikel, sifat fisika dan mekanik

\begin{abstract}
Preparation and characterization mechanical properties of particles board based shells fruit rubber use plastic of polypropylene waste as adhesive has been done. Preparation of the Particle board based shells fruit rubber and plastic of polypropylene addition with variation of 50, 100 and 150 grams. The Particle board was printed on the same size $28 \mathrm{~cm}$ $\times 12 \mathrm{~cm} \times 4 \mathrm{~cm}$. Blending of the internal shell powder and adhesive of polypropylene used a hot press for 1 hour, then settled for 7 days at room temperature. Characterization the particles board includes of the physics and mechanical properties. It is the density $0.81-$ $0.88 \mathrm{~g} / \mathrm{cm}^{3}$, of the water content $0.34-0.93 \%$, water absorption $5.67-10.69 \%$ and the thickness board expansion $0.26-1.62 \%$. The values of MOR and MOE of particle board was $53.00-56.54 \mathrm{kgf} / \mathrm{cm}^{2}$, and $253.85-400.87 \mathrm{kgf} / \mathrm{cm}^{2}$. The values of strong pull secrew was $1.96 \mathrm{kgf} / \mathrm{cm}^{2}$.
\end{abstract}

Keywords: Shells fruit rubber, polypropylene, particle board, physic and mechanical properties 


\section{Pendahuluan}

Kebutuhan manusia terhadap bahan papan pada saat ini mengalami peningkatan yang sangat pesat. Hal tersebut mengakibatkan sumber daya hutan semakin hari semakin berkurang. Untuk mengatasi masalah ini maka diperlukan berbagai usaha seperti efisiensi pemanfaatan kayu secara total atau pengalihan pembuatan papan dari kayu solid menjadi papan partikel dari bahan berlignoselulosa yang bahannya mudah didapat tanpa mengurangi kualitasnya (Ulfah et al., 2015).

Bahan berlignoselulosa terutama bahan-bahan yang dianggap limbah maupun hasil ikutan (by product) telah banyak dikembangkan sebagai bahan baku papan partikel (Kartika et al., 2013). Salah satu bahan berlignoselulosa yang dapat dimanfaatkan sebagai bahan baku papan partikel adalah cangkang buah karet. Hingga saat ini cangkang buah karet belum dimanfaatkan secara optimal, bahkan kadang kala menjadi suatu limbah yang tidak memiliki nilai jual. Salah satu alternatif yang perlu dikembangkan adalah pemanfaatan cangkang buah karet sebagai bahan baku pembuatan papan partikel.

Pada umumnya perekat yang digunakan untuk membuat papan partikel dalam industri adalah urea formaldehida dan fenol formaldehida. Namun penggunaan perekat tersebut akan menghasilkan emisi formaldehida yang cukup tinggi. Emisi formaldehida tersebut jika melebihi standar yang sudah ditetapkan dapat mengganggu kesehatan dan lingkungan. Beberapa penyakit yang telah terdeteksi sebagai akibat dari emisi formaldehida yang berlebih antara lain iritasi mata, penyakit saluran pernapasan bagian atas, gangguan pencernaan, dan sakit kepala (Widyorini et al., 2012). Untuk itu diperlukan alternatif lain bahan perekat yang tidak membahayakan kesehatan maupun lingkungan. Limbah plastik polipropilena diketahui dapat digunakan sebagai bahan perekat pada

p-ISSN 2528-0414

e-ISSN 2528-0422 papan partikel. Setyawati et al, (2006) melaporkan bahwa limbah plastik polipropilena dapat digunakan sebagai bahan dasar maupun pengganti perekat dalam pembuatan papan partikel. Berdasarkan permasalahan yang telah diuraikan diatas, maka perlu dilakukan penelitian mengenai pembuatan papan partikel dari cangkang buah karet dengan perekat limbah plastik polipropilena. Pembuatan papan partikel ini diharapkan dapat menjadi alternatif pengganti kayu sebagai bahan baku papan. Untuk mengetahui kualitas papan partikel tersebut maka akan diuji sifat fisika yang meliputi: kerapatan, kadar air, daya serap air, dan pengembangan tebal. Sifat mekanikyang meliputi: keteguhan patah, keteguhan elastis dan kuat cabut sekrup.

\section{Metode Penelitian}

\section{Alat dan Bahan}

Alat yang digunakan dalam penelitian ini adalah lumpang, alu,gunting, neraca analitik (sartorius tipe BP 4100), oven, cetakan, kompor gas (rinnai), timbangan, sendok, panci, saringan dandang, desikator, gelas piala $500 \mathrm{~mL}$, jangka sorong (prohex) ketelitian $0,05 \mathrm{~mm}$ dan alat press sederhana. Sedangkan bahan yang digunakan dalam penelitian ini adalah cangkang buah karet yang diambil dari perkebunan warga di Desa Bukit Peninjauan II Kecamatan Sukaraja Kabupaten Seluma. Limbah plastik polipropilena yang digunakan berupa limbah kemasan gelas plastik air mineral yang diambil dari tempat penampungan barang bekas di daerah Betungan kota Bengkulu. Bahan lain yang digunakan adalah air.

\section{Prosedur Penelitian}

Bahan baku yang digunakan adalah cangkang buah karet yang dijadikan serbuk. Cangkang buah karet yang diambil dari lokasi perkebunan dicuci hingga bersih lalu dicacah hingga ukuran cangkang menjadi $\pm 0,5 \mathrm{~cm}^{2}$, kemudian cangkang buah karet direbus pada air 
mendidih selama \pm 15 menit. Setelah itu direndam menggunakan air secukupnya selama 7 hari, setiap harinya dilakukan pergantian air. Selanjutnya cangkang buah karet dikering-anginkan lalu ditumbuk hingga menjadi serbuk. Serbuk kemudian diayak menggunakan ayakan 10 mesh. Selanjutnya serbuk dikeringkan dalam oven dengan suhu $103 \pm 2^{\circ} \mathrm{C}$ selama 3 jam untuk mengurangi kadar airnya.

Bahan perekat yang digunakan adalah limbah plastik polipropilena yang berasal dari limbah kemasan gelas plastik air mineral. Limbah plastik tersebut di cuci hingga bersih kemudian dijemur di bawah sinar matahari hingga kering. Selanjutnya plastik digunting hingga ukurannya menjadi $\pm 0,5 \mathrm{~cm}^{2}$. Kemudian plastik ditimbang sebanyak 600 gram (sesuai dengan kapasitas cetakan dan perbandingan terhadap serbuk) untuk 1 cetakan papan partikel, lalu dimasukkan secara bertahap kedalam panci dan dipanaskan hingga plastik tersebut meleleh semua. Plastik yang sudah mencair siap digunakan sebagai bahan perekat.

Plastik polipropilena yang sudah mencair dimasukkan ke dalam cetakan dengan ukuran $28 \mathrm{~cm} \times 12 \mathrm{~cm} \times 4 \mathrm{~cm}$. Kemudian ditambahkan dengan serbuk cangkang buah karet dengan variasi berat 50 gram, 100 gram, dan 150 gram lalu diaduk hingga serbuk cangkang buah karet dan plastik polipropilena tercampur merata. Selanjutnya campuran tersebut dikempa selama 1 jam dalam keadaan panas. Kemudian dilakukan pengkondisian dengan mendiamkan papan partikel selama 7 hari pada suhu kamar.

\section{Hasil dan Pembahasan}

\section{Kerapatan}

Nilai kerapatan papan partikel dari serbuk cangkang buah karet dengan perekat limbah plastik polipropilena berkisar antara $0,81-0,88 \mathrm{~g} / \mathrm{cm}^{3}$. Hasil tersebut menunjukkan bahwa papan partikel dari cangkang buah karet dengan perekat limbah plastik polipropilena memiliki nilai kerapatan yang tinggi. Tingginya nilai kerapatan papan partikel yang dihasilkan dipengaruhi oleh kerapatan bahan baku yang digunakan, pada umumnya semakin tinggi nilai kerapatan bahan baku maka kerapatan papan yang dihasilkan semakin tinggi (Shmulsky dan Jones, 2011). Grafik hasil uji kerapatan papan partikel selengkapnya dapat dilihat pada Gambar 1.

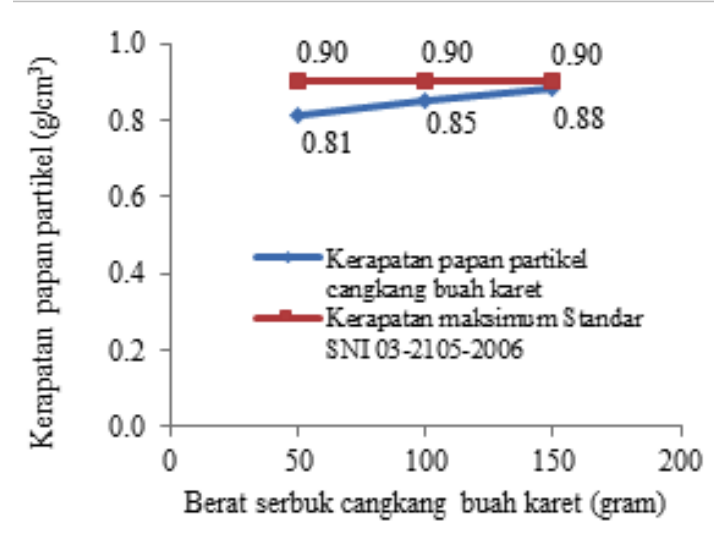

Gambar 1. Grafik hasil uji kerapatan papan partikel dengan variasi berat serbuk cangkang buah karet.

Grafik pada Gambar 1 menunjukkan bahwa nilai kerapatan papan partikel selalu meningkat seiring banyaknya serbuk cangkang buah karet yang digunakan, tetapi peningkatannya tidak signifikan. Peningkatan nilai kerapatan tersebut diduga dipengaruhi oleh jumlah serbuk cangkang buah karet yang digunakan. Semakin banyak serbuk cangkang buah karet yang digunakan maka interaksi gaya tarik intermolekul (ikatan van der waals) semakin banyak sehingga peristiwa adhesi dan kohesi yang terjadi juga akan meningkat dan menyebabkan ikatan antara serbuk cangkang buah karet dan molekul polipropilena semakin kompak dan semakin kuat sehingga nilai kerapatannya akan meningkat. Dari hasil penelitian dapat diketahui bahwa papan partikel 
yang terbuat dari serbuk cangkang buah karet dengan perekat limbah plastik polipropilena memiliki kerapatan yang tinggi dan sudah memenuhi standar SNI 03-2105-2006 yang ditetapkan yaitu 0,4 $0,9 \mathrm{~g} / \mathrm{cm}^{3}$.

\section{Kadar air}

Papan partikel dari serbuk cangkang buah karet dengan perekat limbah plastik polipropilena memiliki persentase kadar air berkisar $0,34-0,93 \%$. Persentase kadar air papan partikel sangat dipengaruhi oleh komposisi bahan yang digunakan. Papan partikel yang dibuat memiliki komposisi serbuk cangkang buah karet yang lebih sedikit dibandingkan dengan plastik polipropilena. Semakin sedikit serbuk cangkang buah karet yang digunakan maka semakin banyak permukaan serbuk cangkang buah karet yang dapat tertutupi oleh plastik polipropilena. Hal tersebut membuat kandungan air yang masih terperangkap di dalam serbuk cangkang buah tidak dapat dikeluarkan. Selain itu papan partikel yang dihasilkan akan bersifat hidrofobik. Grafik persentase kadar air dapat dilihat pada Gambar 2.

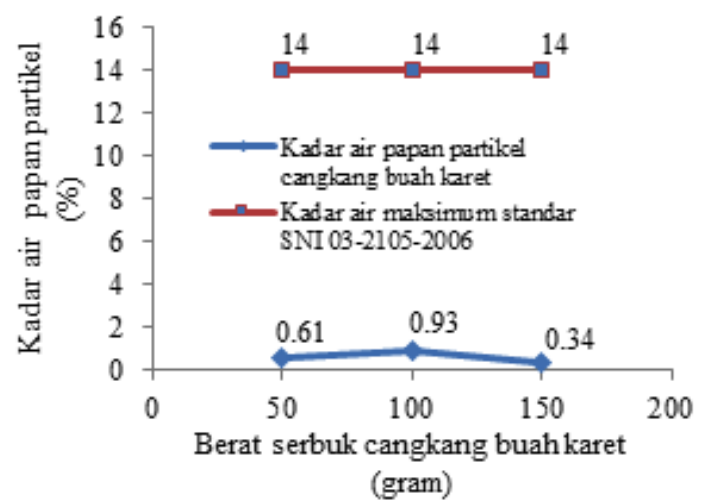

Gambar 2. Grafik hasil uji kadar airpapan partikel dengan variasi berat serbuk cangkang buah karet.

Grafik pada Gambar 2 menunjukkan bahwa persentase kadar air tidak selalu meningkat seiring banyaknya serbuk cangkang buah karet yang digunakan. Papan partikel dengan berat cangkang buah karet 150 gram, persentase kadar airnya mengalami penurunan. Hal tersebut diduga disebabkan karena pada papan partikel dengan variasi serbuk cangkang buah karet 150 gram pada proses perekatan sudah melewati kondisi optimum daerah interaksi. Kondisi optimum daerah interaksi merupakan kondisi dimana rongga pada perekat (matriks) sudah terisi penuh oleh serbuk cangkang buah karet (filler). Jika ditambahkan lagi serbuk cangkang buah karetnya maka akan menyebabkan bertambahnya daerah yang tidak berinteraksi dengan molekul polipropilena (Septiari et al., 2014). Serbuk cangkang buah karet yang tidak berinteraksi dengan molekul polipropilena akan menumpuk dan mengalami peristiwa kohesi antar partikel cangkang buah karet. Sedangkan pada permukaan serbuk cangkang buah karet tersebut juga akan mengalami peristiwa adhesi. Terjadinya kedua peristiwa tersebut secara bersamaan akan menyebabkan interaksi intermolekul semakin kuat dan semakin rapat. Hal tersebut menyebabkan uap air dari dalam papan partikel sulit untuk dikeluarkan sehingga kadar air yang teramati semakin rendah. Dari hasil penelitian tersebut diketahui bahwa papan partikel yang terbuat dari serbuk cangkang buah karet dan limbah plastik polipropilena mempunyai persentase kadar air berkisar antara $0,34-0,93 \%$. Menurut standar SNI 03-2105-2006 yang ditetapkan maksimum 14\%, hal ini berarti semakin rendah kadar air, maka kualitas papan partikel semakin baik.

\section{Daya serap air}

Papan partikel dari serbuk cangkang buah karet dengan perekat limbah plastik polipropilena ini, memiliki daya serap air yang rendah yaitu 5,67 - 10,69\%. Rendahnya persentase daya serap air pada papan partikel tersebut diduga karena penggunaan plastik polipropilena yang bersifat tahan terhadap air (Klyosov, 2007). Semakin banyak perekat 
polipropilena yang digunakan di dalam papan partikel, maka semakin besar bagian permukaan partikel yang dapat tertutupi oleh molekul polipropilena. Hal tersebut akan mengurangi kemampuan serbuk cangkang buah karet pada permukaan papan untuk menyerap air dari lingkungan sekitar. Selain itu papan partikel yang dihasilkan cenderung bersifat hidrofobik, sehingga papan partikel tidak mudah untuk menyerap air meskipun direndam dalam waktu yang lama. Dari grafik pada Gambar 9 terlihat bahwa terjadi penurunan persentase daya serap air pada papan partikel dengan berat cangkang buah karet 150 gram. Hal tersebut diduga disebabkan karena pada papan partikel dengan variasi serbuk cangkang buah karet 150 gram pada proses perekatan sudah melewati kondisi optimum daerah interaksi. Kondisi optimum daerah interaksi merupakan kondisi dimana rongga pada perekat (matriks) yang sudah terisi penuh oleh serbuk cangkang buah karet (filler). Jika ditambahkan lagi serbuk cangkang buah karetnya maka akan menyebabkan bertambahnya daerah yang tidak berinteraksi (Septiari et al., 2014). Grafik hasil uji daya serap air selengkapnya dapat dilihat pada Gambar 3.

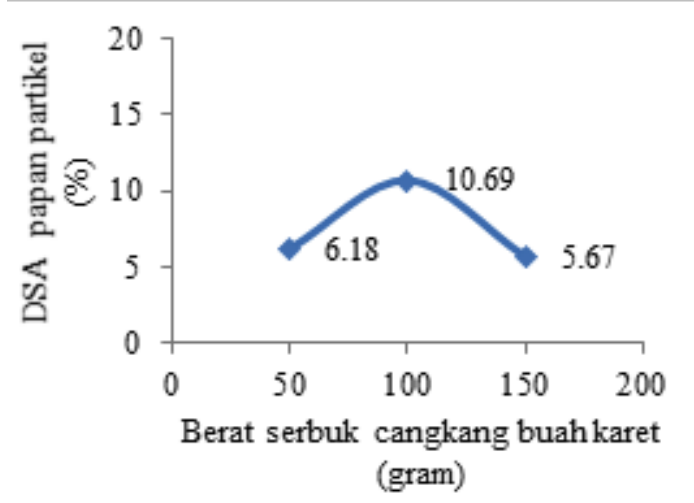

Gambar 3. Grafik hasil uji daya serap air papan partikel dengan variasi berat serbuk cangkang buah karet

Serbuk cangkang buah karet yang tidak berinteraksi akan menumpuk dan mengalami peristiwa kohesi antar partikel

p-ISSN 2528-0414

e-ISSN 2528-0422 cangkang buah karet. Sedangkan pada permukaan serbuk cangkang buah karet akan mengalami peristiwa adhesi. Terjadinya kedua peristiwa tersebut secara bersamaan akan menyebabkan interaksi intermolekul semakin kuat dan semakin rapat, sehingga air sulit untuk terserap. Namun, nilai daya serap air dan pengembangan tebal tidak dipersyaratkan pada standar SNI 03-2105-2006.

\section{Pengembangan tebal}

Persentase pengembangan tebal papan partikel dari serbuk cangkang buah karet dan plastik polipropilena berkisar antara $0,26-1,62 \%$. Grafik hasil uji pengembangan tebal papan partikel dapat dilihat pada Gambar 4. Persentase pengembangan tebal papan partikel dipengaruhi oleh komposisi bahan yang digunakan. Papan partikel yang dibuat memiliki komposisi serbuk cangkang buah karet yang lebih sedikit dibandingkan dengan plastik polipropilena. Semakin sedikit serbuk cangkang buah karet yang digunakan maka semakin banyak permukaan serbuk cangkang buah karet yang tertutupi oleh molekul polipropilena. Hal tersebut akan mengurangi kemampuan serbuk cangkang buah karet pada permukaan papan untuk menyerap air dari lingkungan sekitar. Dari grafik pada Gambar 4 dapat dilihat bahwa pada papan partikel dengan serbuk cangkang buah karet 150 gram persentase pengembangan tebalnya mengalami penurunan. Hal tersebut dipengaruhi oleh persentase daya serap air pada papan partikel. Semakin rendah daya serap air papan partikel maka semakin rendah pula pengembangan tebalnya. Papan partikel dengan variasi berat serbuk cangkang buah karet 150 gram mengalami penurunan persentase daya serap airnya, sehingga membuat persentase pengembangan tebalnya juga akan mengalami penurunan. Hasil persentase pengembangan tebal papan partikel dari serbuk cangkang buah karet dengan perekat limbah plastik polipropilena 
memiliki persentase pengembangan tebal yang sangat kecil. Sehingga papan partikel memiliki stabilitas dimensi yang tinggi.

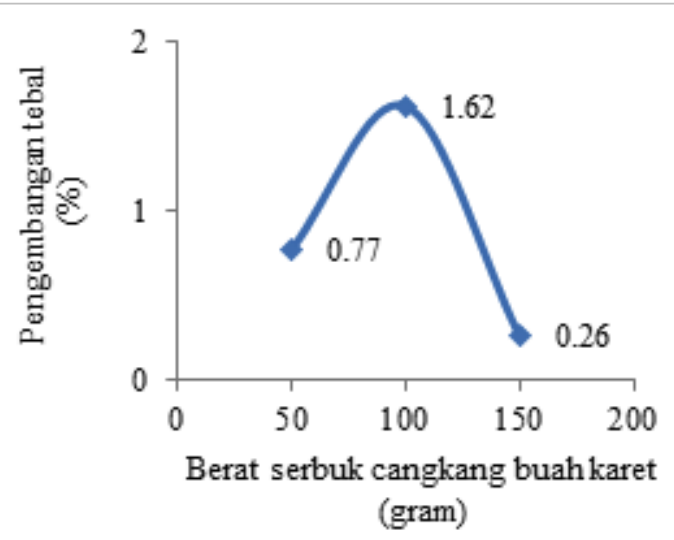

Gambar 4. Grafik hasil uji pengembangan tebal papan partikel dengan variasi berat serbuk cangkang buah karet.

\section{Keteguhan patah}

Papan partikel dari serbuk cangkang buah karet dengan perekat plastik polipropilena memiliki nilai keteguhan patah / MOR $53-56,54 \mathrm{kgf} / \mathrm{cm}^{2}$. Nilai keteguhan patah papan partikel dari cangkang buah karet dengan perekat limbah plastik polipropilena masih sangat rendah, untuk itu perlu dilakukan pengujian keteguhan patah pada papan partikel di pasaran sebagai pembanding. Hasil keteguhan pada papan partikel di pasaran sebesar $77,35 \mathrm{kgf} / \mathrm{cm}^{2}$. Grafik uji keteguhan patah dapat dilihat pada Gambar 5. Pada variasi berat serbuk cangkang buah karet 150 gram nilai keteguhan patahnya mengalami penurunan. Hal tersebut disebabkan karena penggunaan serbuk cangkang buah karet sudah melewati kondisi optimum daerah interaksi sehingga jika ditambahkan lagi serbuk cangkang buah karetnya maka akan menyebabkan bertambahnya daerah yang tidak berinteraksi dengan molekul polipropilena. Serbuk cangkang buah karet yang tidak berinteraksi langsung dengan molekul polipropilena akan menumpuk dan mengalami peristiwa kohesi antar serbuk cangkang buah karet. Akibatnya peristiwa adhesi yang terjadi hanya pada permukaan serbuk cangkang buah karet saja sehingga kekuatan papan akan menurun dan menyebabkan keteguhan patah papan partikel juga akan menurun (Septiari et al., 2014). Hasil pengujian keteguhan patah papan partikel dengan variasi berat cangkang buah karet belum memenuhi nilai keteguhan patah papan partikel di pasaran sebesar 77,35 $\mathrm{kgf} / \mathrm{cm}^{2}$ dan juga belum memenuhi standar SNI 03-2105-2006 yang ditetapkan sebesar $82 \mathrm{kgf} / \mathrm{cm}^{2}$.

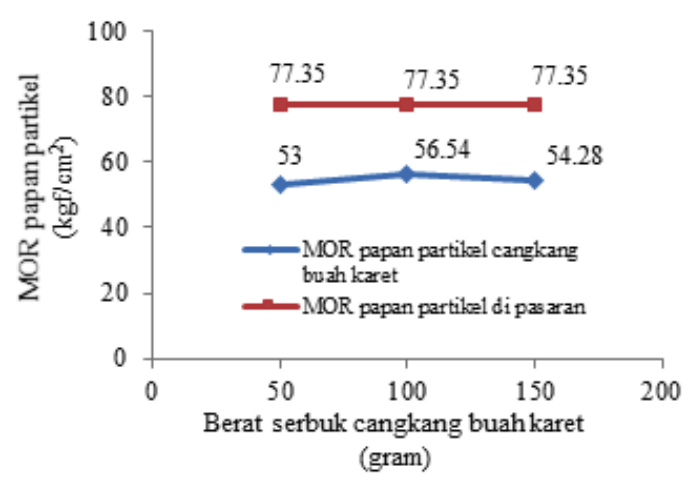

Gambar 5. Grafik uji keteguhan patah (MOR) papan partikel dengan variasi berat serbuk cangkang buah karet.

\section{Keteguhan elastis}

Papan partikel dari serbuk cangkang buah karet dengan perekat plastik polipropilena memiliki nilai keteguhan elastis / MOE berkisar 261,32 - 400,87 $\mathrm{kgf} / \mathrm{cm}^{2}$. Sebagai pembanding maka dilakukan pengujian kuat cabut sekrup pada papan partikel di pasaran. Dari hasil pengujian didapatkan nilai keteguhan elastis papan partikel di pasaran sebesar $1183,65 \mathrm{kgf} / \mathrm{cm}^{2}$. Nilai keteguhan elastis papan partikel dari cangkang buah karet dengan perekat limbah plastik polipropilena dan papan partikel di pasaran masih sangat rendah. Dari hasil penelitian tersebut diketahui bahwa nilai keteguhan elastis terbaik diperoleh pada papan partikel dengan berat cangkang buah karet 50 gram. Tingginya nilai keteguhan elastis tersebut dipengaruhi 
oleh sedikitnya serbuk cangkang buah karet yang digunakan. Serbuk cangkang buah karet yang lebih sedikit menyebabkan cairan perekat dapat membasahi dan tersebar secara merata di atas permukaan dan masuk hingga ke dalam permukaan partikel cangkang buah karet sehingga menyebabkan nilai keteguhan elastis menjadi tinggi Grafik hasil pengujian keteguhan elastis dapat dilihat pada Gambar 6.

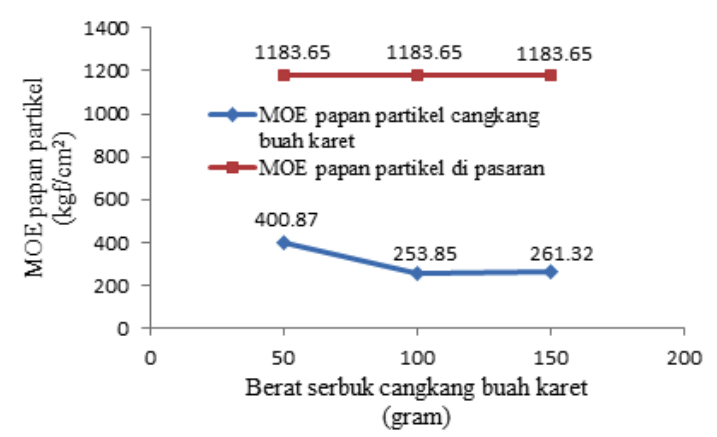

Gambar 6. Grafik hasil uji keteguhan elastis (MOE) papan partikel dengan variasi berat serbuk cangkang buah karet.

Selain itu sedikitnya serbuk cangkang buah karet yang digunakan akan menyebabkan meningkatnya peristiwa kohesi yang terjadi antar molekul polipropilena sehingga keteguhan elastis papan akan meningkat. Bahan perekat dari plastik polipropilena berpengaruh terhadap nilai keteguhan elastis karena plastik polipropilena yang meleleh akan mengisi ruang antar partikel dan mengeluarkan benang-benang plastik yang akan mengikat antara satu partikel dengan partikel yang lain. Hal ini yang dapat meningkatkan ketahanan papan partikel terhadap pembengkokan dan juga membuat papan partikel menjadi lebih lentur (Ujiani, 2007). Hasil pengujian keteguhan elastis papan partikel dari cangkang buah karet dengan perekat limbah plastik polipropilena belum memenuhi standar SNI 03-2105-2006 yang ditetapkan yaitu sebesar 20.400 $\mathrm{kgf} / \mathrm{cm}^{2}$.
Pengujian cabut sekrup hanya dilakukan pada papan partikel yang memiliki sifat mekanik terbaik. Dari hasil penjumlahan nilai keteguhan patah dan keteguhan elastis, papan partikel yang memiliki sifat mekanik yang terbaik adalah papan partikel dengan berat serbuk cangkang buah karet sebesar 50 gram. Papan partikel tersebut memiliki jumlah nilai keteguhan patah dan keteguhan elastis sebesar $400,87 \mathrm{kgf} / \mathrm{cm}^{2}$. Nilai kuat cabut sekrup papan partikel dari cangkang buah karet dengan perekat limbah plastik polipropilena adalah 56,14 kgf. Sebagai pembanding maka dilakukan pengujian kuat cabut sekrup pada papan partikel di pasaran. Hasil kuat cabut sekrup papan partikel di pasaran sebesar 24,16 kgf.

Dari hasil pengujian kuat cabut sekrup pada papan partikel dari cangkang buah karet dengan perekat limbah plastik polipropilena dan papan partikel di pasaran, diketahui bahwa nilai kuat cabut sekrup pada papan partikel dari cangkang buah karet dengan perekat limbah plastik polipropilena sangat tinggi dan lebih baik dibandingkan dengan papan partikel di pasaran. Tingginya nilai kuat cabut sekrup disebabkan oleh penyebaran serbuk cangkang buah karet yang lebih merata sehingga cairan perekat dapat membasahi dan tersebar secara merata di atas permukaan dan ke dalam permukaan. Hal tersebut membuat interaksi intermolekul semakin banyak sehingga peristiwa adhesi dan peristiwa kohesi antar molekul polipropilena juga akan meningkat menyebabkan nilai keteguhan patah dan keteguhan elastis papan partikel menjadi tinggi (Sucipto, 2009). Semakin tinggi nilai keteguhan patah dan nilai keteguhan elastis pada papan partikel maka beban maksimum yang dapat diterima oleh papan partikel hingga sekrup atau paku tercabut dari papan akan semakin tinggi juga.

\section{Kesimpulan}

Papan partikel dapat dibuat dari serbuk cangkang buah karet dan limbah plastik 
polipropilena dengan variasi berat serbuk cangkang buah karet. Papan partikel terbaik diperoleh pada variasi berat serbuk cangkang buah karet 50 gram. Hasil uji sifat fisika papan partikel memiliki nilai kerapatan dan kadar air yang sudah memenuhi standar SNI 032105-2006. Hasil uji sifat mekanik papan partikel memiliki nilai keteguhan patah dan keteguhan elastis yang belum memenuhi standar SNI 03-2105-2006 dan

\section{Daftar Pustaka}

Kartika, I.A., Fahma, F., Yani, M. dan Hermawan, D. (2013). Sifat Fisik dan Mekanik Papan Partikel Bungkil Biji Jarak Pagar. Jurnal Teknologi Industri Pertanian, 23, 109-119

Klyosov, A. (2007). Wood Plastic Composites. Wiley Interscience.

Septiari, I.A.P.W., Karyasa, I.W. dan Kartowarsono, N. (2014). Pembuatan Papan Partikel dari Limbah Plastik Polypropylene (PP) dan Tangkai Bambu. Kimia Visvitalis 2, 117-126.

Setyawati, D., Hadi, Y.S., Massijaya, M.Y., dan Nugroho, N. (2006). Kualitas Papan Komposit Berlapis Finir dari Sabut Kelapa dan Plastik Polietena. Jurnal Perennial, 2, 5-11 papan partikel di pasaran. Sehingga papan partikel tersebut belum memenuhi syarat untuk dipasarkan. Namun nilai kuat cabut sekrup lebih baik dibandingkan papan partikel di pasaran dan sudah memenuhi standar SNI. Banyaknya serbuk cangkang buah karet yang digunakan mempengaruhi sifat fisika dan sifat mekanik papan partikel sampai kondisi optimum daerah interaksi.

Shmulsky, R., and Jones, P.D. (2011). Forest Products and Wood Science An introduction. $6^{\text {th }}$ Ed., JohnWiley $\&$ Sons, Inc.

Sucipto, T. (2009). Teori Adhesi Spesifik Perekat. Karya Tulis. Universitas Sumatera Utara.

Ujiani, N. (2007). Pengaruh Konsentrasi Polypropylene dan Ukuran Partikel limbah Padat Agar-agar Terhadap Kualitas Papan Partikel. Skripsi. Institut Pertanian Bogor

Ulfah, F., Syakhbaniah dan Darvina, Y. (2015). Pengaruh Variasi Komposisi Serat Tandan Kosong Sawit (tks) dan Serbuk Kayu Terhadap Sifat Fisis dan Sifat Mekanis Papan Partikel. Pillar of Physics, 1, 113-120 